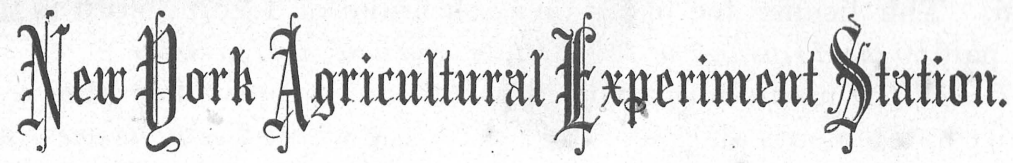

\section{CONCENTRATED FEEDING STUFFS LAW.}

Summary of Feeding Stuffs Law in force in New York after Dec. 1st, 1899.

1. Feeding stuffs not covered by the law:

Hays and straws, and the entire grains of wheat, rye, barley, oats, maize (corn), buckwheat and broom corn, either whole or ground into meal; also bran and middlings from wheat, rye and buckwheat when sold as such.

2. Feeding stuffs which are included in the law:

Linseed meals, cottonseed meals, pea-meals, cocoanut meals, gluten meals, gluten feeds, maize feeds, starch feeds, sugar feeds, dried brewer's grains, malt sprouts, hominy feeds, cerealine feeds, rice meals, oat feeds, corn and oat chops, ground beef or fish scraps, mixed feeds, and all other materials of similar nature.

3. Statement to be affixed to bags or other packages, or to be furnished to dealers with each car or lot sold in bulk:

(a) Trade name of feeding stuff,

(b) Name of manufacturer and place of business,

(c) Place of manufacture,

(d) Percentage of protein,

(e) Percentage of fat.

4. When a buyer purchases a feeding stuff, in bulk or in his own bags, he is entitled to the above statement which must be furnished to him by the seller.

5. The manufacturer must file in the office of this Station annually during December the same statement that is required on the bags, and furnish a sample of each feeding stuff if the Director so requests. These samples are not for analysis. They are requested for the first year as a means of becoming familiar with the various brands. 
6. The license fee of $\$ 25$ on each brand of feeding 'stuff is to be paid to the Treasurer of this Station ann ually in December.

7. If the manufacturer or importer or shipper files the required statements and pays the fee for the whole State no one else is required to pay, but otherwise every retail dealer in the State will be liable. (It is expected that this law will operate as do the fertilizer laws where, without exception, the manufacturers pay the required fees.)

8. Samples of feeding stuffs will be taken in the markets by an authorized agent of the Station to determine whether the law is violated. These are the only samples which the Station will regard as eligible for official analysis.

9. This law makes it illegal to adulterate the cereal grains, corn, oats, etc., with milling or manufacturing waste products, as for instance grinding oat hulls into corn, unless the substances in the mixture are clearly stated on the package. Such adulterations under the head of mixed feeds are much practiced, it is feared, and will be carefully sought for by the Station.

10. It is desired that any persons interested, farmers especially, who become cognizant of feeding stuffs that are illegally sold will notify the Experiment Station to that effect. Samples of materials believed to be adulterated and not so marked, are also requested.

W. H. JORDAN, Director.

Geneva, N. Y., Nov. 15, 1899. 